\title{
Job characteristics model of Hackman and Oldham in garment sector in Bangladesh: a case study at Savar area in Dhaka district
}

\author{
Abu Zafar Ahmed Mukul ${ }^{1}$, Shah Johir Rayhan ${ }^{1}$, Fazlul Hoque ${ }^{2, ~ *, ~ F a i j u l ~ I s l a m ~}{ }^{2}$ \\ ${ }^{1}$ Department of Management \& Finance, (SAU), Dhaka, Bangladesh \\ ${ }^{2}$ Faculty of Agribusiness Management, (SAU), Dhaka, Bangladesh \\ Email address: \\ mukul_mgt@yahoo.com(A. Mukul),johir_rayhan2006@yahoo.com(S. Rayhan), fazlulhoque68@yahoo.com(F. Hoque), \\ Faijulislam1991@gmail.com(F. Islam)

\section{To cite this article:} \\ Abu Zafar Ahmed Mukul, Shah Johir Rayhan, Fazlul Hoque, Faijul Islam. Job Characteristics Model of Hackman and Oldham in \\ Garment Sector in Bangladesh: A Case Study in Savar Area in Dhaka District. International Journal of Economics, Finance and \\ Management Sciences. Vol. 1, No. 4, 2013, pp. 188-195. doi: 10.11648/j.ijefm.20130104.12
}

\begin{abstract}
In the literature related to organizational behaviour management, the effect of job characteristics on employee motivation as a special case has been considered. The present study conducted on the workers of ten garments industries randomly at Savar area in Dhaka, Bangladesh. The 100 sample respondents have been selected from the only workers of garments industries .For this purpose, five properties have been evaluated include skill variety, task identity, task significance, job autonomy and feedback results of work in the form of five hypotheses that affect the motivation of these characteristics is investigated. According to study the workers in garments sector are satisfied by the task identity, task significance, feedback for their activities but they are not happy with the independence work place, skill varieties. They are so motivated by their task identity, task significance, feedback for their performance. The workers are satisfied with the autonomy in workplace and skill variety practice. The workers in garments sector have no freedom in scheduling the work and in determining the procedure to be used in carrying it out. This autocratic management in garments sector influences on workers' productivity, commitment to goal achievement job satisfaction, loyalty, psychological health negatively. Implementation of skill varieties is absent in garment sector for workers .It means job rotation is not done for workers. So the various skill, talent, potentialities of workers are neglected here and do not get any scope of blooming of capacities. This practice in garments sector decreases the chance of workers for career development, make the workers bored with their activities .As result productivity of workers ,morality, motivation are negatively affected.
\end{abstract}

Keywords: Motivation, Job Characteristics, Diversity Skills, Task Identity, Important Task

\section{Introduction}

Almost every country irrespective of its stage of development is engaged in garment manufacturing and trading and almost, without any exception, historically, the readymade industry was the first industry a country was able to introduce which eventually led to the development of other industries. This industry migrates from high-wage to low-wage countries like a "flying goose" (Siddiqi 2005). After the liberation, industrial base here in Bangladesh had to face a sudden vacuum of the entrepreneurs (who were mainly from West Pakistan)

Nevertheless, towards 1980's a new industrial venture, namely, garments manufacturing factories started to grow with some favorable policy support from the Government and preferential treatment of major apparel importing countries by guaranteed share of their market. Although traditionally jute industry dominated the industrial sector of the country until 1970s, but from early 1980s the Readymade Garments (RMG) industry emerged as an important economic sector of the country and gradually replaced the jute industry. There has been a steady growth in RMG exports during the last three decades (Haider 2007). RMG industries enjoyed a dramatic rise from 30 enterprises in 1980 to about 4740 in 2007-2008 fiscal years. According to one statistics whereas in 1983-84 RMG sector employed 0.040 million workers, in 2007-08 this figure increased to 2.500 million (BGMEA 2009). Gross foreign exchange earnings from RMG exports and their contribution to the total export earnings have increased 
significantly over time. The sector's earnings stood US\$ 7.9 billion from US\$ 3.36 million in fiscal year 1981 and in $2007,77.4 \%$ of total export earnings of Bangladesh came from RMG sector. The share of RMG exports in total GDP became 13.1 in FY 2006 compared with $0.16 \%$ in FY 1984. It is important that $80 \%$ of the total workers of RMG sector are women (Khatun, Rahman, Bhattacharya and Moazzem 2008).

Locke (1976), who defined it as pleasurable or positive emotional state resulting from the appraisal of one's job or job experiences. Harter, Schmidt and Hayes (2002) mentioned that 7,855 articles having being published between 1976 and 2000, on job satisfaction. Cole and Cole (www.teammax.) in their study mentioned that majority of the research examining the employee satisfactionperformance relationship has been conducted on the micro level of analysis and a handful of studies have explored the relationship between aggregated employee job satisfaction attitudes and organizational (unit level) performance (Ostroff 1992; Ryan, Schmitt and Jonson

1996; Harter, et.al 2002; Schnieder, Hanges, Smith and Salvaggio2003; Bowen and Ostroff2004; Wright, Dunfold, and Snell 2001; Wright, Gardner, Moynihan and Allen 2005). Cole and Cole mentioned that the current understanding of how aggregated employee attitudes influence and are influenced by important business outcomes is limited and they based on the evidence to date) concluded that employee satisfaction is related to meaningful business outcomes and these relationships generalize across companies (and industries).

Khan (2001) in his study mentioned that there is deliberate feminization of the workforce of the garment industry in Bangladesh.

Delahanty (1998) mentioned that workers of garment factories in Bangladesh frequently suffer from hacking coughs, severe eye strain due to poor lighting and working hours, respiratory problems, low back and joint pain and urinary tract infections because they are denied access to toilet facilities.

Absar (2001) in her study mentioned that Bangladesh has the cheapest unit of labor cost in South Asia. It costs only 11 cents to manufacture a shirt in Bangladesh whereas it costs 79 cents in Srilanka and 26 in India. Rogers (2010) in his writing mentioned that Bangladeshi garment workers are the lowest paid garment workers in the world.

Islam and Swierczek (2003) analyzed the impact of technological change on job satisfaction of women garment workers in Bangladesh. The specific relationship between job satisfaction and the overall impact defined in socio economic terms shows that fair pay; task significance, bureaucracy, conflicts and information sharing are significantly related.

In this study, researchers tried to find out what is the lacking of the owners of the RMG sectors towards then performance enhancements of our garments industry. We found out that the workers are the key success factors of that industry. The garments industry contributes the highest portion of our country's GDP. So enhancing the performance of that industry in terms of diminishing the dissatisfactory factors of the workers may drive our country from developing to a developed one.

\section{Statement of the Problem}

The consequences of job satisfaction are very much important to an organization in terms of its efficiency, productivity, employee relations, absenteeism and turnover and to an employee in terms of his health and well being. Job satisfaction is the function of the perceived relationship between what one expects and obtains from one's job and how much importance or value he attributes to it. The indicators of job satisfaction such as, health, job safety, sustain facilities provided by respective authority, working environment, relationship with co-workers, salary structure, participation in factory management etc. With the end of the view, the present study has been designed to conduct a research work on the workers of various garments industries at Savar in Dhaka District; the socio economic background of employees, job satisfaction, job dissatisfaction and their consequence as the related issue.

\section{Objective of the Study}

The main objectives of the study are as follows:

1. To evaluate the social background of the workers in Garments Sectors

2. To find out the constraints of achieving job satisfaction

3. To identify the determinants of workers motivation in Garments sector

\section{Rationale of the Study}

There are many employees' are engaged in the private sectors organization in Bangladesh. They are involving with a huge number of problems. But they don't get scope to express their opinion to the higher authority due to stress, fear, lack of knowledge etc. On the other hand they have a limited power to find out the actual problem involving with their job. The private sector organizations of our country are involving with strike, bribe, slowdowns, noncooperation, lock out etc. Only by the help of job satisfaction it is possible to overcome. The knowledge of job satisfaction is very much important to understand their problems at the workplace. But no substantial work has so far been conducted on socio economic background, job satisfaction and job security of the non-government organizations; especially on garments industries at Savar area in Dhaka District. So it is very essential to conduct a research study on levels of job satisfaction in workers of garments industries. 


\section{Limitations of the Study}

On the way of this study researcher has faced the following problems, which in terms may be considered as the limitations of the study. These are as follows:

1. The researcher could not spend sufficient time, which was required for the in-depth study.

2. The study mostly limited to only the 100 workers out of the 500000 workers of garments industries at Savar area in Dhaka District; which may be more in number for getting more accurate result.

3. Corrective measures for identified problems are not covered in it due to lack of experience.

All the respondents do not give answer correctly

\section{Theoretical Framework}

Job characteristics theory (Hackman and Oldham. 1976, 1980) describes the relationship between job characteristic and individual responses to work. The theory specifics the task condition inwhich individuals are predicted to prosper in their work. There are five job dimension prompting three psychological states that lead to some beneficial personal and 'work outcomes. The theory also include individual difference variables as moderator of the relationship between the characteristics and the outcome variables.

Hackman and Oldham $(1976,1980)$ define the five job characteristics as follows:
Skill variety: the degree to which a job requires a variety of different activities in carrying out the work, involving the use of a number of different skills arid talents of the person.

Task identity: the degree to "which the job requires completion of a whole, identifiable piece of work that is doing a job from beginning to end with visible outcome.

Task significance: the degree to which the job has a substantial impact on the lives of other people, whether those people are in the immediate organization or in the world at large.

Autonomy: the degree to which the job provides substantial freedom, independence, and discretion to the individual in scheduling the work and in determining the procedure to be used in carrying it out.

Job feedback: the degree to which carrying out the work activities required by the job provides the individual with direct and clear information about the effectiveness of his or her performance.

It is possible to combine the five characteristics into a single index that reflects the overall motivating potential of a job. In the model (see Figure1) specific job characteristics. i.e. skill variety, task identity $\backslash$ and task significance, affects the individual's experience meaningfulness of work, autonomy influences experienced responsibility for outcomes: and feedback from job to knowledge of the actual results of the work activities This leads to the formula of motivating potential score (MPS) as follows:

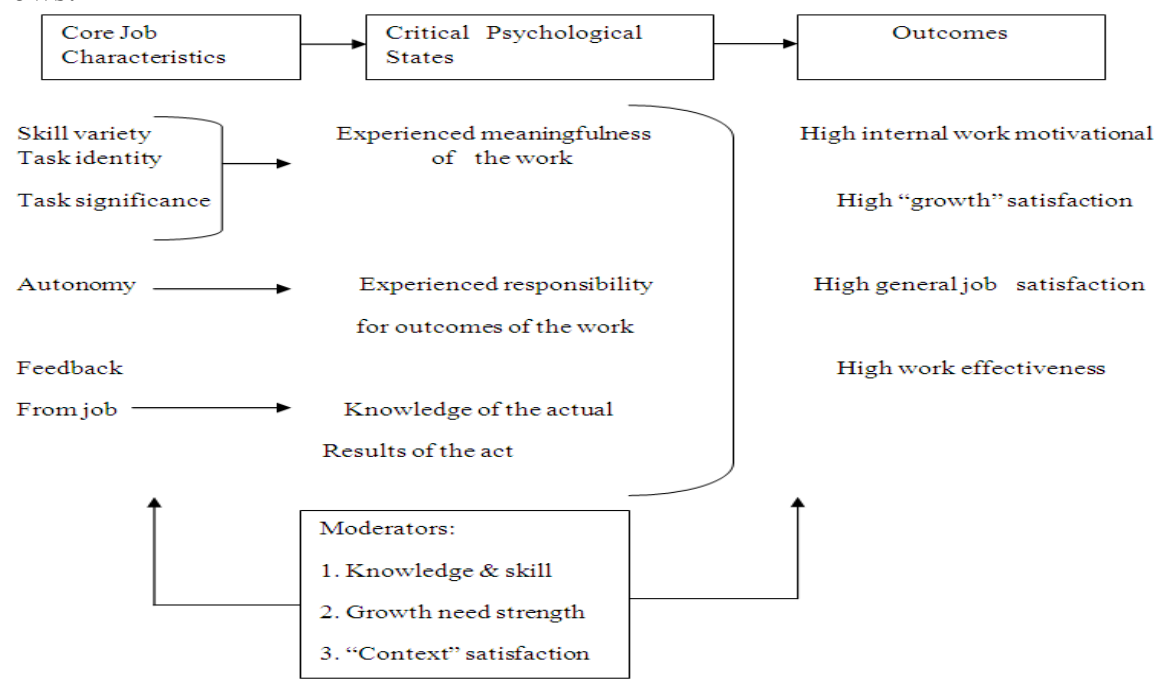

(From Hackman and Oldham, 1980,p.90)

Figure1. The Job Characteristics Model

Hackman and Oldharn $(1976,80)$ recognized that not all employees will respond positively to a job high in motivating potential. There are three characteristics of people which are especially important in moderating both the job characteristics - psychological states relationship, as well as the psychological states outcome relationship (Hackman and Oldham, 1980: Kulik, Oldham and Hackman. 1987). They are knowledge' and skill to perform the work, growth need strength, and work context such as pay, job security, coworkers, and managers. At the link between the job characteristics and the psychological states, when the job characteristics and the psychological states, when the job characteristics arc good, it is more likely that psychological states will be experienced if moderator variables are high, especially growth need strength than if moderator variables are low. Referring to the link between the psychological states and outcome variables, individuals with high moderator variables respond more positively to 
experience of psychological states. In this condition, better outcomes can be predicted.

MPS $=\{$ skill variety + task identity + task significance $) / 3$ ) $\mathrm{x}$ autonomy $\mathrm{x}$ feedback.

Hackman and Oldham (1976. 1980) define three psychological states in their theory. To experience the work as meaningful is to feel that the work the individual does is generally worthwhile, valuable, or important by some system of values he or she accepts. The individual experience personal responsibility means that he or she feels personally accountable for the results of the work he and /or she does. Finally, the person who has knowledge of the results of one's work knows and understands how effectively he or she is performing the job. According to job characteristics theory, all three of the psychological states must be experienced by an individual if desirable outcomes are to emerge.

If any one of three psychological stats is not present several outcome variables such as motivation and satisfaction will be weakened. The theory emphasizes that the most important outcome variable is internal motivation which exists when good performance is an occasion for self-reward and poor performance prompts unhappy feelings. Other predicted outcomes are growth satisfaction, general job satisfaction work effectiveness quality work performance, absenteeism and turnover. Growth satisfaction is a feeling that one is learning and growing personally or professionally at work General satisfaction reflects responses to unspecified .work conditions as measured by questions such as generally speaking how satisfied are 'you with your job? ( Hackman and Oldham,1980:89) .work effectiveness includes quality and quantity of the goods or services produced.. Quality work performance can be measured by for instance the number of errors made by employees Absenteeism is the easiest to measure if there is an available work attendance record in a given period. Since the unit analysts of job characteristics model is the individual turnover is simply defined is the intention to quit the employee's Job.

There is an essential proposition in the theory that positive feelings follow from good performance and negative feelings follow from poor performance. If a job low in motivating potential (measured by Job Diagnostics Survey as Motivating Potential Score or MPS), outcomes will be low, and one's feelings will not be influenced much by how well one does. On the other hand, if a job is high in MPS, good performance will be reinforcing and poor performance will result in unhappy feelings. In high MPS jobs, people who are competent to perform well will have positive feelings as a result of their work activities. In contrast, people who do not have enough knowledge and skill to do well will feel unhappy or frustrated.

Growth need strength,that is the degree to which people have need for personal growth and development, can be very crucial in determining response to a job high in motivating potential. People who have high growth need strength will be Likely to "respond enthusiastically to the opportunities for personal accomplishment, learning and developing themselves provided by a job high in motivating potential" (Kulik et a!., 1987). Others who have less strong need for growth will be less Likely to want to exploit the opportunities for personal growth and development.

The theory also predicts that reactions of employees to jobs with high motivating potential will be affected by their satisfaction as aspects of the work context. As mentioned by O'Brien (1982) and Kulik et al (1987), if employees are not satisfied by one or more of these contextual factors, especially payment their performance cannot be maximum

\section{Methodology}

In the present study, methodology is taken to indicate the underlying principles and methods or organizing and the systems or inquiry procedure leading to completion of the study. This chapter deals with various methodological issues relating to the study like profile of the sample unit, sample size of the respondents, sources of data and analysis of data used in the study. There are many garments industries at Savar area in Dhaka District but among them we have collected data from 10 garments industries such a Skyline Group ,Renoka GarmentsLtd Sahariar GarmentsLtd ,Oli Knitting Febrics Ltd ,Ector Febrics Ltd ,IDS Group, Young One Hightech Sportswear Ltd, Beximco Ltd ,Fountain Ltd ,ONUKA Ltd. have been selected for the purpose of my study

\subsection{Sample Size of the Respondents}

The present study conducted on the workers of ten garments industries randomly at Savar area in Dhaka, Bangladesh. Total 10000 workers are working in these industries Limited. Out of the total 10000 workers, only 100 workers have been selected randomly for the study purpose. The 100 sample respondents have been selected from the only workers of garments industries.

\subsection{Sources of Data}

Both primary and secondary data are used for the purpose of the study. The study is mainly based on primary data. The primary data have been collected through personal interview of the workers of garments industries. Different types of data and their sources are discussed under the following heads.

\subsubsection{Primary Data}

The primary data have been collected through personal interview with the workers used by structured questionnaire. To collect the primary data researcher used three sets of interview schedules, specially prepared in the light of the objectives of the study. The collected data have been subsequently processed, tabulated and analyzed for the purpose of the study. The collected data have been processed, tabulated and analyzed in the logical manner. 


\subsubsection{Secondary Data}

The data could not be collected from primary sources have been obtained through secondary sources. The secondary sources include books, journals, annual report and unpublished research works. The collected data have been analyzed through the following statistical instruments:

\subsection{Job Enrichment in Practice}

Different studies indicate that job enrichment reduces costs related to absenteeism and staff handling their job satisfaction (Emami et al., 2012) increases. But the increased production and productivity of sufficient evidence is available (Mousakhani and Monshizadeh, 2005).

Similarly, studies performed widely within the pattern of job characteristics are confirmed, but one thing that is important for the success of job enrichment, managers must have conceptual skills are high (Sneeney and Mcfarlline, 2002). For this purpose the five characteristics of job characteristics have been evaluated include skill variety identity, job, job significance, job autonomy, job feedback results, that most of the five

Hypotheses affect the motivation of these characteristics is discussed.

1) The Identity of Task, on worker motivation operating garment sectors is effective in Bangladesh.

2) The diversity of skills, on worker motivation operating garment sectors is effective in Bangladesh.

3) The Importance of task, on worker motivation operating garment sectors is effective in Bangladesh.

4) The Autonomy in Work, on worker motivation operating garment sectors is effective in Bangladesh.

5) The Feedback in Work, on worker motivation operating garment sectors is effective in Bangladesh.

Before analysing the tables will be noted that in measuring the effects of different levels of a variable on another variable to the analysis of variance, the independent variables at different levels dependent variable are compared with each other and if this means that at these levels differ are zero is rejected and if the means of statistically identical and are not difference is zero is accepted.

Table 1: Task identity

\begin{tabular}{cccc}
\hline & & Frequency & Percent \\
\hline Valid & strongly agree & 18 & 18.0 \\
& agree & 76 & 76.0 \\
& neither agree/disagree & 1 & 1.0 \\
& disagree & 5 & 5.0 \\
& Total & 100 & 100.0 \\
\hline
\end{tabular}

Source: Field survey march, 2013

From the above table, it may said that task identity is strongly maintained in garment sector in Bangladesh .Every worker is authorized to do an identifiable piece of work from beginning to end for visible outcome .workers(94\%) are highly satisfied with task identity . it is one of the most motivating factors in garments sector. So hypothesis about task identity is accepted.

Table 2: Skill variety

\begin{tabular}{cccc}
\hline & & Frequency & Percent \\
\hline Valid & strongly agree & 11 & 11.0 \\
& Agree & 9 & 9.0 \\
& neither agree/disagree & 16 & 16.0 \\
& Disagree & 31 & 31.0 \\
& strongly disagree & 33 & 33.0 \\
& Total & 100 & 100.0 \\
\hline
\end{tabular}

Source: Field survey march, 2013

From the above table we may say that implementation of skill varieties is absent in garment sector for workers. The workers have no opportunities to utilize their varieties skill and talent.It means job rotation is not done in garment sector for workers .The workers $(63 \%)$ are not satisfied with the practice of skill variety.So the hypothesis about skill variety not accepted

Table 3: Task significance

\begin{tabular}{cccc}
\hline & & Frequency & Percent \\
\hline Valid & strongly agree & 31 & 31.0 \\
& agree & 36 & 36.0 \\
& neither agree/disagree & 3 & 3.0 \\
& disagree & 25 & 25.0 \\
& strongly disagree & 5 & 5.0 \\
Total & 100 & 100.0 \\
\hline
\end{tabular}

Source: Field survey march, 2013

From the table it may be said that workers(65.7\%) are happy with the task significance shown by the management level. The top management considers the task done by workers has a substantial impact on the lives of other people, whether those people are in the immediate organization or in the world at large. The hypothesis about task significance is accepted.

Table 4: Autonomy

\begin{tabular}{cccc}
\hline & & Frequency & Percent \\
\hline Valid & strongly agree & 11 & 11.0 \\
& agree & 39 & 39.0 \\
& neither agree/disagree & 3 & 3.0 \\
& disagree & 37 & 37.0 \\
& strongly disagree & 10 & 10.0 \\
& Total & 100 & 100.0 \\
\hline
\end{tabular}

Source: Field survey march, 2013

From the above table it may be described that the wokers in garments sector have no freedom in scheduling the work and in determining the procedure to be used in carrying it 
out. In this sector only skilled labourer enjoys some what freedom in work place. ) The Autonomy in Work, on worker motivation operating garment sectors is not effective in Bangladesh .So hypothesis abotut autonomy is not accepted.

Table 5: Feedback

\begin{tabular}{cccc}
\hline & & Frequency & Percent \\
\hline Valid & strongly agree & 8 & 8.0 \\
& disagree & 55 & 55.0 \\
& neither agree/disagree & 11 & 11.0 \\
& disagree & 20 & 20.0 \\
& strongly disagree & 6 & 6.0 \\
& Total & 100 & 100.0 \\
\hline
\end{tabular}

Source: Field survey march, 2013.

Most of the workers(61.7\%) who carrying out the work activities in garments industries are ensured by direct and clear information about the effectiveness of his or her performance.So the hypothesis about feedback on workers is accept.

\subsection{Socio Economic Information of Garments Workers in Bangladesh}

Table 6: Sex of worker

\begin{tabular}{lccc}
\hline & & Frequency & Percent \\
\hline Valid & male & 25 & 25.0 \\
& female & 75 & 75.0 \\
& Total & 100 & 100.0 \\
\hline
\end{tabular}

Source: Field survey march, 2013

From the above table it may be said that female workers are more interested in doing job in in garments sector. Since male workers may have many options for doing job in various sectors. Due to limited mobility and limited job sectors for lower educated female, they choose to work in garments sector.

Table 7: Age of worker

\begin{tabular}{cccc}
\hline & Frequency & Percent \\
\hline & $15-20 \mathrm{y}$ & 49 & 49.0 \\
$21-30 \mathrm{y}$ & 28 & 28.0 \\
Valid & $31-40 \mathrm{y}$ & 20 & 20.0 \\
& 40 and above & 3 & 3.0 \\
& Total & 100 & 100.0 \\
\hline
\end{tabular}

Source: Field survey march, 2013

From the above table we can say that $97 \%$ of workers are below 40 years. In garment sector there is practice of child labour employment as mentioned $49 \%$ of workers are ageing (15-20) years. It is very difficult for workers aged above 40 years to perform their duties. It means young energetic ,healthy, active people are necessary for garment sectors.

Table 8: Education of worker

\begin{tabular}{cccc}
\hline & & Frequency & Percent \\
\hline Valid & Primary(1-5) & 33 & 33.0 \\
& junior secondary(6-8) & 35 & 35.0 \\
& Secondary(9-10) & 30 & 30.0 \\
& highersecondary(11-12) & 2 & 2.0 \\
& Total & 100 & 100.0 \\
\hline
\end{tabular}

Source: Field survey march, 2013

Above table describe that $98 \%$ of garment workers are educated below higher secondary.It means garment workers are lower educated, they less opportunities to find job in various public and private sectors. As a result they get employed in garments industries .

Table 9 :Occupation of house holds head

\begin{tabular}{cccc}
\hline & Frequency & Percent \\
\hline Valid & day labor & 44 & 44.0 \\
& small farmer & 31 & 31.0 \\
& medium farmer & 17 & 17.0 \\
& large farmer & 8 & 8.0 \\
& Total & 100 & 100.0 \\
\hline
\end{tabular}

Source: Field survey march, 2013

From the above table we can say that Most of workers are belongs to family of headed day labor, small farmer. It means workers grow up in poverty and attempt to get a job for helping their family.

Table 10: Marital status

\begin{tabular}{cccc}
\hline & & Frequency & Percent \\
\hline Valid & single & 32 & 32.0 \\
& married & 37 & 37.0 \\
& divorced & 31 & 31.0 \\
& Total & 100 & 100.0 \\
\hline
\end{tabular}

Source: Field survey march, 2013

It may be said from above table that $37 \%$ are married, $32 \%$ are single and $31 \%$ are divorced.

In male dominated society, lot of female are getting separation from conjugal life due to various reasons such as dowry. As a result they come to Dhaka and trying to get job in garment sector. 


\section{List of Problems}

1. Low salary according to the cost of living.

2. Insufficient recreational facilities.

3. Lack of job training facilities.

4. Lack of safety in work place in emergency period.

5. Lack of canteen facilities.

6. Lack of childcare facilities.

7. Lack of transport facilities.

8. Lack of medical facilities.

\section{Findings \& Recommendation}

The general examination was performed on jobs; jobs became clear motivation is low power, so to solve this problem it is recommended that businesses get evaluated and redesigned them for necessary measures taken comes. According to study the workers in garments sector are satisfied by the task identity, task significance, feedback for their activities but they are not happy with the independence work place,skill varieties. They are so motivated by their task identity, task significance, feedback for their performance. So much needs to motivate workers that the workers in garments sector have no freedom in scheduling the work and in determining the procedure to be used in carrying it out It means workers are fully responsible to execute the order of management level .this autocratic management in garments sector influences on workers productivity, commitment to goal achievement, job satisfaction ,loyalty, psychological health negatively. The Autonomy in Work, on worker motivation operating garment sectors is not effective in Bangladesh

From the above study we may say that implementation of skill varieties is absent in garment sector for workers .It means job rotation is not done for workers. So the various skill ,talent, potentialities of workers are neglected here and do not get any scope of blooming of capacities. This practice in garments sector decreases the chance of workers for career development, make the workers bored with their activities.As result productivity of workers ,morality, motivation are negatively affected.

Autonomy in workplace and facilities for using variety of skill to the workers can be an important factor for workers motivation stack is investigated. Therefore, organizations must be responsible for designing jobs paid enough attention to the fact that.

We can be different according to the needs and motivation of people in different cities and even in a city and various organizations as can be determined for the organizational goal for participation in organizational decision making for organizational career development and other organizational workflow for the occupational used to increase workers motivation levels. Motivational theories in position and job status is a major issue of employment and workers in some occupations are satisfied with the internal management and therefore must set the content of jobs that workers do it with pride and will enjoy.
On the other hand it became clear that "Though the need for variable adjustment of growth" in third world countries cannot be as an adjustment variable Though the model affected by Hackman and Oldham does, because people in these countries is still low levels of their needs are involved. Words, with the help of Maslow theory of motivation can be as low level to satisfy the needs of the individual not to need to grow (their needs flourishing) does not consider. In fact, because most workers do not think the variable needs to grow and provide livelihoods affected are minimum requirements and the need for better from this model, at least in developing countries be removed.

\section{Conclusion}

Based on the study findings of this study, it could be concluded that job characteristics play an important role to identify differences and similarities between jobs and to determine workers' job satisfaction. Overall, the results of the present study were no significant relationship between workers' job characteristic and their job satisfaction. It was being observed that most workers reported moderate or low mean score for perceiving their job characteristics and job satisfaction. From the background data of workers (above90\%) are educated less than secondary level,75\% of female, ageing less than 30 years ,female where more than $40 \%$ divorced and household heads are mostly day labour and small farmers .From the demographic it may be said that garment workers are helpless in their societies. So they are bound to take in any garments industries without considering wage, healthcare benefits, job duties, safety, autonomy, task identity ,task significance ,skill variety, feedback, participation in management ,bonus, recreational facilities etc. The most of workers are not aware about job satisfaction and job characteristics .It has been cleared to us that the workers are not satisfied with their salary ,bonus package ,recreational facilities are fully absent ,health care ,behaviour of management level. They think that salary and bonus package are most effective to increase job satisfaction. From analyise of data that although the workers are not aware about job characteristics but they expect specific task identity, task significanc, skill variety, feedback, independence in workplace. They think these variables may positively influence the job satisfaction and helps to increase productivity, morale ,loyalty, commitment to goal of organization.

From above data it has been noted that workers are satisfied with their task identity task significance,feedback of job. They are not satisfied with autonomy and skill varieties practices. So the management should take any decision in democratic ways so that workers do not think them inferior and provide facilities to utilize their various talents and skill.

And in a society that believes there is such a motivating ways employees are considered useless. However, the achievements of scholars in the field of organizational behaviour motivation and job characteristics are 
appreciable, but it is noteworthy that these theories should be tailored to the needs of staff and community and cultural organizations to localize. Finally, based on the evidence mentioned can be said with confidence that a) people working in occupations with high rates of five indicators were generally more motivated, satisfied and have higher productivity 2) indices on the job behaviour or mental state affect and work output variables, not the individuals themselves (Robbins, 2005).

\section{References}

[1] Absar, Syeda Sharmin. 2001. Problems Surrounding Wages: the Ready Made Garment Sector in Bangladesh. Labour and Management in Development Journal, 2(7), ISSN: 14436698, Asia Pacific Press-2001

[2] BGMEA. 2009. http://www.bgmea.com/data.htm \& http://bgmea.com/pro.htm

[3] Delahanty , Julie. 1998. Higher Pay at a Higher Price for Bangladeshi Garment Workers. Review, 2(1), North South Institute, www.nsiins.ca/english/publications/review/v2n1/03.asp

[4] Emami, R., Moradi, E., Idrus, D., Almutairi, D.O. (2012). Investigating the relationship between organizational learning culture, job satisfaction and turnover intention in it SMEs, International Journal of Innovative Ideas, 12(1), 8-23

[5] Haider, Mohammed Ziaul. 2007. Competitiveness of the Bangladesh Readymade Garment Industry in Major International Markets. Asia- Pacific Trade and Investment Review, 3 (1), June. www.unescap.org/tid/publication/aptir

[6] Hackman J.R. \& Oldham G.R. (1980). Work Redesign. Philippines : Addison- Wesley

[7] Hackman,J.R.andOldham,G.R(1976)Motivation through the design of work:Test of a Theory.Organisational Behavior and Human Performance,16,250-279

[8] Harter, J.K., F. L. Schmidt and T.L. Hayes. 2002. BusinessUnit Level Relationship between Employee Satisfaction, Employee Engagement, and Business Outcomes: A Meta Analysis. Journal of Applied Psychology, 87:268-279

[9] Islam and Swierczek. 2003. Job Satisfaction Impact of
Technological Change on Women Garment Workers in Bangladesh. Journal of Business Administration, 29 (1\&2 (January \& April). Dhaka, Bangladesh: Institute of Business administration

[10] Khatun, Fahmida, Mustafizur Rahman, Debapriya Bhattacharya, Khondaker Golam Moazzem. 2008. Gender and Trade Liberalisation in Bangladesh- The Case of the Readymade Garments. Research Monograph- 2. Dhaka, Bangladesh: Centre for Policy Dialogue (CPD)

[11] Khan, S.I. 2001. Trade Unions, Gender Issues and the Ready-Made Garment Industry in Bangladesh. www.unrisd.org/.../8DDEE7A220A7A155C1256D5500425 415

[12] Kulik,C.T.,Oldham,G.R. and Hackman,J.R.(1987)Work Design as an Approach toPerson- Environment fit.Journal of Vocational Behavior,31,278-296.

[13] Kulik,C.T.,Oldham,G.R. and Langer,P.H. (1988)Measurement of JobCharacteristics:Comparison of the Original and theRevised Job Diagnostic Survey.Journal of Applied Psycology,73(3),462-466.

[14] Locke, E.A. 1976. The Nature and Causes of Job Satisfaction. Chicago IL: Rand McNally

[15] MousaKhani, M. (2005). Monshizade Nayin,Masoud, Organization and Management, Islamic Azad University of Qazvin, c. 2, Tehran.

[16] O'Brien,G.E(1982) Evaluation of the Job Characteristics Theory of Work attitudes and Performance.Australian journal of Psycology,34(3).383-401.

[17] Rogers, William. 2010. Fire Kills Garment Workers: Workers Protest Low Wages. The working conditions and wages of workers in the Bangladesh. leftlaborreporter.wordpress.com/2010

[18] Ryan, A.M., M.J. Schmitt and R. Jonson. 1996. Attitudes and Effectiveness: Examining relations at an organizational level. Personal Psychology, 49: 853-882

[19] Siddiqi, G. Hafiz. 2005. The Readymade Industry of Bangladesh, (Second Edition). Dhaka, Bangladesh: The University Press Limited

[20] Sneeney, P. Mcfarlin, D. (2002). Organizational Behavior, Solutions for Management, McGraw-Hill international Editions 